\title{
Lives and Afterlives of Bushidō: A Perspective from Overseas*
}

\author{
William M. BODIFORD**
}

\begin{abstract}
Bushidō has had many different lives in many different places around the world. These transformations and afterlives constitute valuable witnesses that offer competing narratives of Japan's modern development and of its changing roles in the world. Beyond Japan they speak to the multiple ways that the country both inspires and (sometimes) displeases other nations. These lives and afterlives also serve to illustrate the myriad ways that intersections of the local and translocal, the past and present, refract perspectives. Bushidō is not unique in its ability to assume divergent connotations and implications in accordance with the contours of the frame within which it is placed. Its elusiveness exemplifies the amorphous characteristics of our global world's nomadic lexicon.
\end{abstract}

Keywords: bushidō, Nitobé, invention of tradition, nomadic concepts

\section{Bushidō kot hibrid: hibridnost in transkulturacija v diskurzu o bushidōju Izvleček}

Bushidō je imel v različnih krajih po vsem svetu različne izpeljave. Njegove preobrazbe in zapuščina so dragoceno pričanje o medsebojno konkurenčnih pripovedih o sodobnem razvoju Japonske in njenih spreminjajočih se vlogah v svetu. Zunaj Japonske med drugim pričajo o različnih načinih, na katere Japonska navdihuje in (včasih) tudi razočara druge države. Ta življenja in zapuščine služijo tudi za ponazoritev neštetih načinov, na katere križanja lokalnega in translokalnega, preteklosti in sedanjosti na novo vzpostavljajo perspektive. Bushidō ni edinstven v svoji zmožnosti, da privzema različne konotacije in implikacije znotraj okvirja, v katerega je umeščen. Njegova izmuzljivost kaže na brezobličnost nomadskega besedišča današnjega globaliziranega sveta.

Ključne besede: bushidō, Nitobé, izumljanje tradicije, nomadski koncepti

* Revised from a presentation at the University in Ljubljana, 2017, international symposium on Bushidō in Transformation. I wish to thank Professor Nataša Visočnik for making this event possible.

** William M. BODIFORD, Professor, Asian Languages \& Cultures, UCLA, USA. bodiford[at]ucla.edu

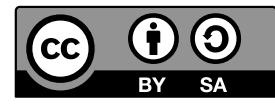




\section{Essay}

Bushido has never been more popular than it is today. Popularity is difficult to measure, but we can gain a rough idea simply by looking at the number of books published in Japan with the word "bushido" 武士道 as part of their title, which has increased dramatically over the past decade (see Table 1). During the early twentieth century, after Nitobé Inazo ${ }^{1}$ 新渡戸稲造 (1862-1933) first popularized the concept of "bushidö" as "the Soul of Japan" (as he translated the word in the title of his bestselling book), Japan saw a similarly large number of books on the topic, although thereafter the number declined. After the end of the Pacific War the Japanese public ignored bushido, and from 1945 to 1959 only about seven books with the word "bushido" in the title were published in the country. During the 1960s, 1970s, and 1980s some interest returned, with an average of about 32 titles published in each decade. Beginning in 2010, however, publishers in Japan began to release an ever rising number of books on bushido, publishing more than 150 different titles in the space of just seven years. This might simply be due to the advent of online publishing, which has lowered the cost of production. But even inexpensive books will not be published if readers do not wish to purchase them.

More important is the fact that interest in bushido has increased not just inside Japan but throughout the world. Some indication of this can be seen by looking at the number of times that Nitobés original English-language book was reprinted in other countries or translated into the languages of those nations (see Table 2). Nitobé published the first edition of his book in Philadelphia, USA, in 1900. Within that same decade there appeared nine more editions in English in both the United States and Britain as well as seven translations: German (1901) by Kaufmann, Czech (1904) by Karel Hora, Polish (1904) by H. Altenberga, Norwegian (1905) by Hans Brekke, Russian (1905) by A. Salmanovoj, Japanese (1909) by Sakurai Ōson 櫻井鷗村 (1872-1929), and Spanish (1909) by Gonzalo Jiménez de la Espada. No other Japanese author had enjoyed success on this scale, not just in United States or Britain, but across Europe. Thereafter Nitobés explanation of bushido declined in importance, and was all but ignored until the 1980s, when six new translations appeared: Italian (1980) by Rinaldo Massi, Chinese (1982) by Su Guizhen 蘇癸珍, Japanese again (1983) by Naramoto Tatsuya 奈良本辰也 (1913-2001), German (1985) by Rinaldo Massi (again), Malay (1986) by Wong Seng Tong, and Spanish again (1989) by Esteve Serra. Since then its reprinting and translation have continued every decade, and Nitobé's book has never been so widely read as it is today.

1 I spell Nitobé with an accent in accordance with the way it appears on the cover page of his book. 
Nowadays even academic researchers show interest in bushidō. Previously scholars of Japan had mostly ignored bushidō or dismissed it as a loose popular construct without analytic value. Their disregard was not unreasonable. Authors writing for the general public had used the word "bushido" in reference to such disparate phenomena that its use in scholarly writing could too easily invite confusion. One rough indication of this lack of interest can be seen by searching for its use in scholarly databases. The widely used academic repository JSTOR (http://www. jstor.org/), for example, currently boasts that it provides on-line access to more than 10 million academic journal articles (most of which are published in English) across seventy-five scholarly disciplines. A search for the title-word "bushidö" yields only five results (one in the 1980s, two in the 1990s, and two since 2000). In contrast, a search for the title-word "samurai" (another rather vague term) results in 69 publications, more than twelve times as many.

This academic neglect ended in 2014 when Oleg Benesch published Inventing the Way of the Samurai: Nationalism, Internationalism, and Bushido in Modern Japan (Oxford University Press). Benesch presents a masterful overview of the complex modern history of the term bushido and all the debates in Japan over its meaning and significance. His book is essential reading for scholars of modern Japanese history and culture. Benesch's study focuses exclusively on the intellectual history of bushido within Japan, not its influence elsewhere in the world. He demonstrates that Japanese intellectuals began articulating various interpretations of bushidō even before Nitobés English-language book appeared, and that, contrary to our previous understanding, Nitobé contributed little to their debates. According to Benesch, Nitobé's exposition of the "Soul of Japan" failed to exert much influence within Japan, even after it was translated into Japanese. People who want to better understand how most Japanese have understood bushido and the role that it played in pre-1945 nationalism, must therefore look beyond Nitobé's account. For this purpose, Benesch's work is invaluable.

Benesch presents bushidō as an invented tradition of modern Japan. The concept of invented tradition does not refer to the re-invigoration of an existing tradition or the revival of a dormant one. It refers, rather, to the ways that "the modern"- especially modern social organisations and modern ideologies-will harken back to romanticized pristine and timeless past precedents as a mechanism to strengthen group cohesion and forge new identities. Eric Hobsbawm (1983a; 1983b) helped popularize this concept in his analysis of the emergence of nationalism during the period 1870 to 1914 in Europe. Subsequent historians demonstrated its applicability to many aspects of modern culture. Numerous Japanese examples serve as case studies in Mirror of Modernity: Invented Traditions of Modern Japan, a volume of essays edited by Steven Vlastos (1998). 
Benesch analyses how educators and public intellectuals transformed the previously obscure term bushido into an all-purpose label for a wide variety of traits that they linked to a shared national identity, loyalty to the imperial cause, and an ethic of self-sacrifice. His explanation of bushido as an invented tradition is especially convincing with regard to the late nineteenth and early twentieth centuries, when advocates of bushido first grappled with the contradictions of modernity and presented diverse and even contradictory interpretations as they struggled to forge a broad cohesive vision for society. This process of invention was recognised and debated at that time. As early as 1912, for example, Basil Hall Chamberlain (1859-1935) famously dismissed bushidō as part of The Invention of a Nerw Religion. This analysis of bushidō as an invention proves less successful in Benesch's discussions of the new and diverse contexts in which bushido discourse has reappeared in recent decades (which Benesch, p. 2, lists as popular culture, politics, sports, economics, business, and natural disasters), when the social and political conditions within and outside Japan changed greatly from those seen when bushidō was invented. The invention of tradition cannot account for the remarkably long-lasting resilience, multi-faceted connotations, and persistent cultural relevance of bushidō as both a term and concept.

To better understand these afterlives of bushidō we must examine it not just as a term within this or that discourse, but also its many lives as a concept. While terms typically begin life by referring to concrete references within an identifiable context, they also can assume afterlives as abstract concepts which scholars then use as active interpretive agents of analysis (Hall 1983, 3-4). Interpretive concepts derive their meaning or significance less from their context than from their relative positionality within theoretical frameworks, the boundaries of which can shift as individual writers frame topics differently or extend their explanations in new directions. Concepts increase in usefulness by acquiring new theoretical connotations to facilitate intellectual exploration. As new connotations accrue to the same underlying term (bushido, in this case), this conceptual expansion invites lexicographical dissonance. Readers who lack awareness of the author's interpretive framework can easily misunderstand his or her assertions.

Bushidō is not unique in its ability to assume divergent connotations and implications in accordance with the framework within which it is placed. Its elusiveness exemplifies the amorphous characteristics of our global world's nomadic lexicon, not just in the humanities but also in the sciences and social sciences. There exists, for example, a growing literature on "traveling concepts" (e.g., Bal 2002; Forsdick 2001; Karp 1997; McGuckin 2005; Said 1982 and 1994) and on "nomadic concepts" (Braidotti 1993; Joris 1998 and 1999; Stengers 1987). Olivier Christin (2010; also see 2017) in his Dictionnaire des concepts nomades en sciences bumaines compiled a lexicon of common terms (such as: administration; avant-garde; 
borders; humanitarian; intelligentsia; labour; public opinion; secularize; the West; etc.) that seem simple but convey such conceptual weight so as to pose difficulties for effective communication. ${ }^{2}$

In a world in which even ordinary words complicate understanding, can it be surprising that bushido has acquired so many different nuances within and outside Japan? In this essay I will focus on the overseas afterlives of bushido as a concept. In focusing on its conceptualization, I want to exclude from consideration the roles of bushidō in budō (i.e., Japanese martial arts). Its embodiment in regimes of discipline and performance-the bushido that Alexander Bennett (2013) says the Japanese people do not know-raises too many complex issues for consideration here. ${ }^{3}$ Before exploring the myriad permutations of bushido, first I will provide some simple examples of how concepts travel and become nomadic. My examples concern the term "religion". This word is a good place to start, because Chamberlain already implicated it in the invention of bushido, and because it is well known and widely used, although most people have only vague ideas about it, while scholars of religion employ it in rather complex and contradictory ways. Moreover, "religion" itself is a concept of rather recent invention (Smith 1998; Masuzawa 2005). Its invention and evolution illustrates how shifting frameworks allow concepts to become more useful: successful concepts perform the intellectual work of revealing relationships which otherwise pass unnoticed, while facilitating the construction of new social realities which would otherwise lack coherence.

Jonathan Z. Smith $(1998,269)$ identifies a key characteristic of religion as follows: "it is a category imposed from the outside"-usually by Europeans on other cultures they encounter and subjugate. It is a concept that thus travelled from Europe to the rest of the world. In the case of Japan, it was not just imposed from abroad, but also-as demonstrated by Jason Josephson in his masterful The Invention of Religion in Japan (2012, 195-6, 225ff) - became a tool of the Japanese governing elites, who imposed it from above onto their countrymen below. Josephson's account charts not just how the invention of religion played a key role in the creation of modern Japan, but also how the concept of religion opens a discursive space populated by fellow travellers who provide it with its conceptual, social, and legal power. A précis of a few of his points follows.

First, as a conceptual category religion makes it possible to admit the existence of more than one kind of Christianity (i.e., Christian religions as opposed to

2 In their original languages these entries are: administration; avant-garde; frontiere; humanitaire; intelligencija; laïcite; travailt; opinion publique; occident.

3 Regarding this topic, see the works of Gainty 2013, Inoue 1998 and 2004, Shooklyn 2009, and Yuasa 2001, as well as the other essays in this volume. 
the one religion of Christ). Over time this ecumenicalism would be expanded to admit the existence of religions (plural) as a generic category, within which Christianity could be but one example (even if it always occupies the position of the best example; pp. 15-16). In short, the conceptualization of the term entails the admission of multiple iterations of its referent. Second, this conceptualization forces the imposition of boundaries, as efforts to refine the concept generate debates over what it includes or excludes. The boundaries of religion necessarily entail creating opposing concepts, such as the non-religious (secular), superstition, and pseudo-religion. It seems only natural, therefore, that early theories of secularization imagined it as a process of disenchantment in which religion would gradually become confined to personal beliefs, while politics, industry, and society, being freed of religious confinement, would follow the march of rational, scientific progress (pp. 95-96; see Figure 1). Third, concepts become nomadic by crossing boundaries and co-opting their opposites. ${ }^{4}$ Modern societies do not, in fact, see a decline in religious thinking, but instead imbue politics and science with a "regime of truth" expressed by symbols, slogans, ceremonies, and specific ideologies that are all but indistinguishable from the so-called religious (pp. 135-6; see Figure 2.1). Likewise, religions ally themselves with science, reason, and the secular state to work against the superstitious, the pseudo-religious, cults, extremism, radicalism, or anything else deemed to be dangerous (136, 224ff; see Figure 2.2). These diverse nomadic qualities of religion as a concept (as opposed to the fixed dogma of a given religion) testify to its analytical and social usefulness.

Can the same be said of bushidö? What intellectual work does it facilitate?

Nitobé's conceptualization of bushidō certainly had a purpose. He published his English-language book in 1900, a turbulent time halfway in between Japan's 1895 war with the Qing Empire of China and its 1905 war with Czarist Russia. Japan was just then beginning to assert itself on the world stage, and sought to escape from the unequal treaties that had been imposed on it by the Americans and European powers. According to his preface, Nitobé (1900, v) wrote Bushido: The Soul of Japan, to answer this simple question: How can the Japanese impart moral education without religion? When Nitobé first encountered this question, Europeans and Americans regarded any society without religion as immoral, uncivilized, and dangerous (Josephson 2012, 202-3), and Nitobé thus sought to assuage their fears. He argues that Japanese society rests on a firm moral foundation, which he identifies as bushidō. He describes it in terms of Chinese Confucian virtues, which he explains through examples drawn primarily from European literature (Powles 1995, 109). In this way bushidō serves to bring Chinese and European ethical

4 Josephson uses the Hegelian term sublation (aufhebung). 
ideals into conversation with one another through the crucible of Japan. Bushidó always remains Japanese in character even as it exemplifies the best qualities of Chinese and European civilizations. Nitobé gave life to bushidō as a nomadic concept, which looks back to Japan's historical past to provide moral direction for its future development, thus addressing the concerns of religious thinkers, but without commitment to any one religious dogma. Its inherent elusiveness allowed readers to flesh out its contours based on their own ideals and expectations of what kinds of teachings would be most suitable for such a moral system.

Moreover, through bushidō Nitobé turned Japan's lack of religion (i.e., Christianity) into an advantage. He performed intellectual jujutsu, in which the weak succeed by relying on the strength of their opponent (Hearn 1985, 187, 193). Through his pen the moral sentiments of Japan's overseas critics not only appeared on Japanese soil, but also travelled back to America and Europe in a secular guise that in the eyes of many rendered them more suitable for modern societies, precisely because they had shed their ties to particular religious' affiliations. Theodore Roosevelt (1858-1919), the President of the United States from 1901 to 1909, wrote that he was "most impressed by [Nitobés] little volume on Bushido," from which he especially learned how the samurai spirit "has been and is being transformed to meet the needs of modem life" (Burdick 1999, 82). In 1904 Beatrice Webb (1858-1943), the founder of the Fabian Society (an influential British socialist organisation dedicated to progressive democratic reforms) lauded Japan as a model of a socially responsible nation and described the country as "a rising star of human self-control and enlightenment" (Holmes and Ion 1980, 320). These statements reveal a major shift in the sentiments of Western leaders and their publics alike. Whereas just a few decades earlier they had regarded the samurai as primitive two-sworded assassins who attacked foreign visitors in cold blood, they now praised the samurai spirit as the animating force behind Japan's transformation into a modern nation (Lehmann 1984, 765-7). People in the West and around the world began to see Japan — and bushido-as a model of how to harness local cultural ethos to build a successful modern state.

This image of bushido as the successful combination of the East and West found favour not just in Europe but also, and especially, in Asia, where European domination in the form of unequal treaties (China) or colonialization (elsewhere) was still the norm. Many Asian intellectuals and local leaders saw bushidō as the key to Japan's success in defending itself against the West. One of the earliest non-Japanese advocates of bushidō in Asia was Liang Qichao 梁啟超 (1873-1929), a Chinese reformist who had been exiled from the Qing Empire of China (and who lived in Japan ca. 1898-1911). In 1904 he wrote (and published in Shanghai) a book titled Bushidō for China (Zhongguo zhiwushidao 中國之武士道). Liang did not advocate importing 
bushido from Japan, but rather advocated that people in China must celebrate their heritage and honour Chinese military heroes to promote their own military ethos (Chen 2010; Liang 1904; Tsai 2010). The fact that the exact same logograms (i.e., 武士道) used to write bushidō in Japanese also are used to write wushidao in Chinese helped Liang to universalize bushido, and free it from its Japanese context.

Eventually similar efforts would appear across Southeast Asia. For example, in 1938 Manuel Quezon (1878-1944), the President of the Philippines, ordered all schools to teach bushido. He stated that four centuries of colonial rule under the Spanish and Americans had eroded the national character of the Filipino people. They needed something like bushidō to instil moral character, vocational efficiency, and an awareness of the duties of citizenship (Goodman 1987,62). That same year Luang Phibunsongkhram (1897-1964; a.k.a. Phibun or Pibul), the Prime Minister of Thailand, promulgated a national code of valour, which he called wiratham, and which he had formulated as a Thai equivalent to bushido (Thamsook 1978, 240). In Spain, José Millán-Astray (1879-1954), the founding commander of the Spanish Foreign Legion and a veteran of Spain's military campaigns in the Philippines, published his own translation of Nitobé's book (based on the French translation of 1927) with instructions that it be distributed for free to Spanish youth. In the preface to his translation, Millán-Astray states that the Legionnaire Code of Honour (Credo Legionario), which he composed, had been inspired by Nitobé's book (Beeby and Rodríguez 2009, 222-5). In Southeast Asia, Nitobé's book was translated into Burmese (in 1942 by U Bha Son') and into Indonesian (in 1944 by Tun Sri Lanang). Significantly, the post-war leaders of these two countries- Ne Win (1911-2002) of Burma (now Myanmar) and Haji Suharto (1921-2008) of Indonesia-were veterans of local military units organised, trained, and directed by their Japanese occupiers (Lebra 1975).

The Pacific War gave the world a new vision of bushidō. In association with Japanese military aggression it caused the image of "human self-control and enlightenment", once praised by Beatrice Webb, to give way to tales of inhumanity. After 1945 Nitobé's book fell out of print. It was supplanted by works with titles like: Bushido: The Anatomy of Terror (by Pernikoff, 1943), Knights of Bushido: A History of Japanese War Crimes (by Russell,1958; reprinted 2002), Beasts of Bushido (by Owen, 1967), or Under the Heel of Bushido (by Sugarman, 2014). As indicated by Russell's subtitle, these books focus on tales of war crimes and atrocities committed by the Japanese military during the Pacific War. Aside from their contents (which cannot be ignored) these works have at least two noteworthy features. First, they provide no description or conceptualization of bushido. While all of them use the word "bushido" in their titles, none of them discuss the term or explain the role it would have played in these episodes. It seems that the authors of these books (and their 
audiences) regarded bushidō as something obviously loathsome and repulsive, something that did not require any explanation or contextualization. This negative evaluation helps explain why almost no books about bushidō were published in the immediate post-war period. The second key feature of these books about the horrors of bushido lies in their chronology. They have been published regularly: in the 1940s, 1950s, 1960s, and 2000s. Even nowadays when people around the world express a resurgence of interest in the positive image of bushido presented by Nitobé, the demonic negative image of bushidō still persists. As a nomadic concept it occupies the opposing positions of the civilized and barbaric.

Among Japan's Asian neighbours, at least, the end of the Cold War seems to have given new life to bushidō. Since the 1980s, there has been a remarkable renaissance of interest in Nitobé's work, and his original English account has been translated ever more often. Library catalogues list at least seven modern translations into Southeast Asian languages: Thai (in 1965 by Sathīan Phantharangsī), Malaysian (in 1986 by Wong Seng Tong), Filipino (in 1990 by Buenaventura Medina, Jr.), Indonesian twice (in 1992 by Yayasan Karti Sarana; and again in 2008 by Antonius R. Pujo Purnomo), and Vietnamese twice (in 2006 by Trung Quốc and Nguyễn Hải Hoành; and in 2011 by Le Ngọc Thao). There exist at least eight recent translations into Chinese: in 1982 by Su Guizhen 蘇癸珍; in 1992 by Zhang Junyan 張俊彥; in 2003 by Wu Rongchen 吴容宸; in 2004 by Fu Songjie 傅松 洁; in 2006 by Chen Gaohua 陈高华; in 2006 by Zong Jianxin 宗建新; in 2009 by Zhiu Yanhong 周燕宏; and in 2012 by Xu Ying 徐颖. And there are at least two recent translations into Korean: in 2002 by Lee Man-Hee and in 2010 by the Ilbon Go Jon Yongu-ho (i.e., 日本古典研究會).

It is too early to tell how Japan's neighbours will reconcile the negative images of wartime bushidō with the bushidō of timeless optimism depicted by Nitobé. Yet it is safe to say that one of the key features of bushido lies in its nomadic ability to embody opposing values simultaneously. While this essay focuses primarily on the afterlives of bushido outside Japan, its conceptualization tends to collapse the dichotomy between inside and outside. Or, rather, in a process that Yoshioka Hiroshi 吉岡洋 of Kyōto University describes as a kind of "self-colonization" of the Japanese imagination, it facilitates the creation of a new discursive space located in between the inside and outside. While the Japanese escaped the harsh realities of being colonialized (e.g., partition, displacement, or slavery), they nonetheless crafted a quasi-colonial subjectivity in response to the rapid pace of social, political, and industrial transformations. According to Yoshioka's analysis, Japanese created a two-fold "othering" of themselves. On the one hand, they crafted a cultural stereotype of the samurai warrior, which they could see as authentically Japanese while also distancing themselves from it as something other, not themselves. This 
cultural stereotype can then be examined and debated as made up of either positive or negative examples of traits to be emulated or avoided. Simultaneously, the Japanese have become masters of various technologies, sciences, and arts from all regions of the world, especially Europe. They can thus see themselves as exemplars of Western learning and accomplishments. These exemplars are at once Japanese yet not Japanese. They likewise can be examined and debated as either positive or negative examples of traits to be emulated or avoided.

Yoshioka's analysis shows how the conceptualization of bushidō helps create new discursive spaces for the nomadic identities of traditional versus contemporary, of native versus international, to be examined and negotiated. Perhaps the renewed popularity of Nitobés bushidō reflects the growing need among its admirers and critics around the world to engage in similar negotiations.

\section{Appendix}

Table 1: "Bushidō" editions published: Editions (first imprints and subsequent reprints) of books with the word "bushidō" 武士道 in their titles available in Japan, arranged chronologically by date of publication and counted by decades. ${ }^{5}$

$\begin{array}{ll}1890 \mathrm{~s} & =3 \\ 1900 \mathrm{~s} & =87 \\ 1910 \mathrm{~s} & =137 \\ 1920 \mathrm{~s} & =9 \\ 1930 \mathrm{~s} & =53 \\ 1940-44 & =56 \\ 1945-49 & =1 \text { (written by a non-Japanese) } \\ 1950 \mathrm{~s} & =6 \\ 1960 \mathrm{~s} & =27 \\ 1970 \mathrm{~s} & =36 \\ 1980 \mathrm{~s} & =34 \\ 1990 \mathrm{~s} & =64 \\ 2000 \mathrm{~s} & =19 \\ 2010-17 \mathrm{~s} & =151\end{array}$

5 Based on a title search via the CiNii Database (http://ci.nii.ac.jp/) for Citation Information provided by the Japanese National Institute of Informatics (Kokuritsu Jōhōgaku Kenkyūsho 国立情報 学研究所): http://ci.nii.ac.jp/books/ search?advanced=true\&count=20\&sortorder=3\&type=0\&title=武士道\&include_utl=true\&update_keep=true . This list includes only works written in Japanese with the exception of English-language editions of Bushido: The Soul of Japan - An Exposition of Japanese Thought (1900) by Nitobé Inazō 新渡戸稻造 (1862-1933) as well as translations of that work in to Japanese and other languages. 
Table 2: Nitobé editions published

\begin{tabular}{|l|c|c|c|c|c|c|c|c|c|c|c|c|c|}
\cline { 2 - 13 } \multicolumn{1}{c|}{} & $\begin{array}{l}\text { Eng- } \\
\text { lish }\end{array}$ & $\begin{array}{l}\text { Ger- } \\
\text { man }\end{array}$ & Czech & $\begin{array}{l}\text { Pol- } \\
\text { ish }\end{array}$ & $\begin{array}{l}\text { Rus- } \\
\text { sian }\end{array}$ & $\begin{array}{l}\text { Japa- } \\
\text { nese }\end{array}$ & $\begin{array}{l}\text { Span- } \\
\text { ish }\end{array}$ & $\begin{array}{l}\text { Ital- } \\
\text { ian }\end{array}$ & French & $\begin{array}{l}\text { SEA- } \\
\text { sian }\end{array}$ & $\begin{array}{l}\text { Chi- } \\
\text { nese }\end{array}$ & $\begin{array}{l}\text { Ko- } \\
\text { rean }\end{array}$ & $\begin{array}{l}\text { Slove- } \\
\text { nian }\end{array}$ \\
\hline $1900 s$ & 9 & 1 & 1 & 1 & 1 & 1 & 1 & & & & & & \\
\hline $1910 s$ & 4 & 2 & & & & & & 1 & & & & & \\
\hline $1920 s$ & & & & & & & & & 1 & & & & \\
\hline $1930 s$ & 3 & 1 & & & & 3 & & & & & & & \\
\hline $1940 s$ & & & & & & & 1 & & & 2 & & & \\
\hline $1950 s$ & & & & & & & & & & & & & \\
\hline $1960 s$ & 1 & & & & & 1 & & & & 1 & & & \\
\hline $1970 s$ & 2 & & & & & 1 & & & & & & & \\
\hline $1980 s$ & & 1 & & & & 2 & 1 & 1 & & 1 & 1 & & \\
\hline $1990 s$ & 2 & 1 & & & & 5 & 2 & 1 & & 2 & 1 & & \\
\hline $2000 s$ & 9 & 5 & & 1 & 2 & 14 & 2 & 1 & 1 & 2 & 5 & 1 & \\
\hline $10-17$ & 4 & & & & 1 & 9 & & & & 2 & 1 & 1 & 2 \\
\hline
\end{tabular}

Table 3: Editions and translations of Nitobés Bushido: The Soul of Japan published each decade $1900 \mathrm{~s}=16$

English original 9

German trans 1

Czech trans 1

Polish trans 1

Norwegian 1

Russian trans 1

Japanese trans $\quad 1$

Spanish trans 1

1910s = 7

English original 4

German trans 2

Italian trans 1

$1920 \mathrm{~s}=2$

French trans 1

Romanian trans 1

1930s $=7$

English original 3

German trans 1

Japanese trans 3 
$1940 \mathrm{~s}=3$

SEA Burmese 1

SEA Indonesian 1

Spanish trans 1

1950s

\begin{tabular}{|c|c|}
\hline & $-0-$ \\
\hline 1960s & $=3$ \\
\hline & English original \\
\hline & Japanese trans \\
\hline & SEA Thai \\
\hline $1970 s$ & $=3$ \\
\hline & English original \\
\hline & Japanese trans \\
\hline $1980 s$ & $=8$ \\
\hline & German trans \\
\hline & Japanese trans \\
\hline & Spanish trans \\
\hline & Italian trans \\
\hline & SEA Malay \\
\hline & Chinese trans \\
\hline
\end{tabular}

1990s $=14$

English original 2

German trans 1

Japanese trans 5

Spanish trans 2

Italian trans 1

SEA Filipino 1

SEA Indonesian 1

Chinese trans 1

2000s $=44$

English original 9

German trans 5

Polish trans 1

Romanian trans 1

Russian trans 2

Japanese trans 14

Spanish trans 2

Italian trans 1

Danish trans 1

SEA Indonesian 1 
SEA Vietnamese $\quad 1$

Chinese trans 5

Korean trans 1

2010-17 = 24

English original 4

Polish trans 1

Russian trans 1

Japanese trans 9

Spanish trans 1

French trans 2

SEA Vietnamese 1

Chinese trans 1

Korean trans 1

Finish trans 1

Slovenian trans 2

\begin{tabular}{|c|c|c|c|c|}
\hline Public policies & warfare & $\begin{array}{c}\text { Premodern societies } \\
\text { religious }\end{array}$ & $\begin{array}{l}\text { Modern societies } \\
\text { rational / scientific }\end{array}$ & $=$ secular \\
\hline$\uparrow$ & government & " & 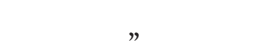 & (disenchanted) \\
\hline i & economics & $"$ & $"$ & \\
\hline I & art & $”$ & $”$ & \\
\hline 1 & work & $"$ & 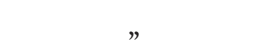 & \\
\hline i & friends & $”$ & & \\
\hline$i$ & family & $”$ & religious & $=$ limited sphere \\
\hline $\begin{array}{l}1 \\
1\end{array}$ & individual habits & 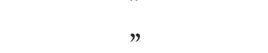 & $”$ & \\
\hline$\stackrel{\downarrow}{\downarrow}$ & belief / values & $”$ & $”$ & \\
\hline
\end{tabular}

Figure 1. Early theories of secularization 


\begin{tabular}{|c|c|c|c|c|}
\hline $\begin{array}{c}\text { Public policies } \\
\uparrow\end{array}$ & warfare & $\begin{array}{c}\text { Premodern societies } \\
\text { no religion / no secular } \\
\text { customs }+ \\
\text { innovations }\end{array}$ & $\begin{array}{c}\text { Modern societies } \\
\text { both religion \& secular } \\
\text { secular }\end{array}$ & $\begin{array}{l}=\text { religion as } \\
\text { unreal } \\
\text { (re-enchantment) }\end{array}$ \\
\hline 1 & government & $"$ & $”$ & \\
\hline 1 & economics & $”$ & $"$ & reinforced by \\
\hline I & art & $"$ & $"$ & religious \\
\hline 1 & & & & symbolism / \\
\hline I & work & $”$ & $"$ & motifs \\
\hline 1 & friends & $”$ & & \\
\hline $\begin{array}{l}1 \\
1\end{array}$ & family & $”$ & religious & $=$ religion as real \\
\hline I & individual habits & 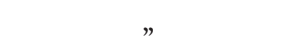 & ” & reinforced by \\
\hline $\begin{array}{c}\mathbf{I} \\
\mathbf{I} \\
\downarrow \\
\text { Private values }\end{array}$ & belief / values & $"$ & $"$ & $\begin{array}{l}\text { group practice } \\
\text { and } \\
\text { individual faith }\end{array}$ \\
\hline
\end{tabular}

Figure 2.1. Secularization reexamined

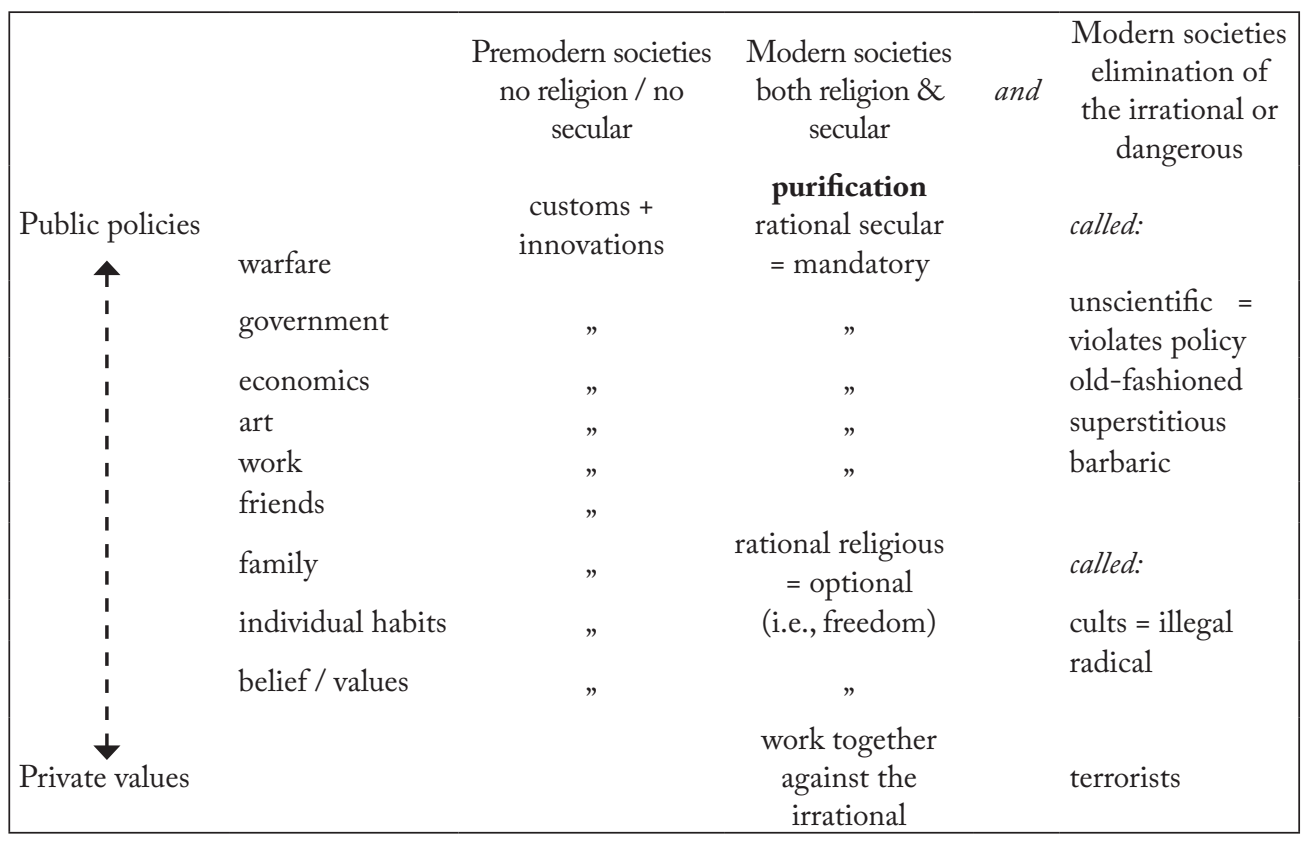

Figure 2.2. Religion reexamined 


\section{References}

Bal, Mieke. 2002. Travelling Concepts in the Humanities: A Rough Guide. Toronto: University of Toronto Press.

Beeby, Allison, and María Teresa Rodríguez. 2009. "Millán-Astray’s Translation of Nitobe's Bushido: The Soul of Japan.” Meta: journal des traducteurs 54: 218-32.

Bennett, Alexander [Benetto Arekisandaa ベネット・アレキサンダー]. 2013. Nihonjin no shiranai bushido 日本人の知らない武士道 (Bushido that Japanese Don't Know). Bunshun Shinsho 文春新書 926. Tokyo: Bungei Shunjū.

- 2017. Bushido and the Art of Living: An Inquiry into Samurai Values. [Translation of Bennett 2013.] Tokyo: Japan Publishing Industry Foundation for Culture.

Benesch, Oleg. 2014. Inventing the Way of the Samurai: Nationalism, Internationalism, and Bushidō in Modern Japan. Oxford: Oxford University Press.

- 2014. "The Samurai Next Door: Chinese Examinations of the Japanese Martial Spirit." Extrême-Orient Extrême-Occident 38: 129-68.

Braidotti, Rosi. 1993. "Embodiment, Sexual Difference, and the Nomadic Subject.” Hypatia 8: 1-13.

Burdick, Dakin Robert. 1999. “The American Way of Fighting: Unarmed Defense in the United States, 1845-1945.” Ph.D. dissertation. Indiana University.

Chamberlain, Basil Hall (1859-1935). 1912. The Invention of a Nerw Religion. London: Watts \& Company. Accessed November 15, 2017, https://www. gutenberg.org/files/2510/2510-h/2510-h.htm.

Chan, Stephen. 2000. "The Construction and Export of Culture as Artifact: The Case of Japanese Martial Arts." Body E' Society 6: 69-74.

Chen, Jidong 陳繼東 . 2010. “Zai zhongguo faxian wushidao: Liang Qichao de changshi 在中國發現武士道: 梁啟超的嘗試 (Discovering Bushidō in China: Endeavours of Liang Qichao).” Taiwan dongya wenming yanjiu xuekan 臺灣東亞文明研究學刊 7: 219-54.

Christin, Olivier. 2010. "Introduction." In Dictionnaire des concepts nomades en sciences humaines, edited by Olivier Christin, 11-23. Paris: Métailié.

—. 2017. “Fuyū suru gainen’o dō toraeru ka 「浮遊する概念」をどう捉える か (How to Capture 'Floating Concept').” Translation [of Christin 2010] by Omata Rappō Hitomi 小俣ラポー日登美 and Iyanaga Nobumi 彌永信美. Shisōo 思想 1116: 32-54.

Forsdick, Charles. 2001. "Travelling Concepts: Postcolonial Approaches to Exoticism.” Paragraph 24: 12-29.

Friday, Karl F. 1994. "Bushidō or Bull? A Medieval Historian’s Perspective on the Imperial Army and the Japanese Warrior Tradition." The History Teacher 27: 339-49. 
Gainty, Denis. 2013. Martial Arts and the Body Politic in Meiji Japan. London: Routledge.

Goodman, Grant K. 1987. "Nitobe's Bushido.” In Festschrift in Honor of Dr. Marcelino Foronda, Jr., edited by Emerita S. Quito. Manila: De La Salle University Press.

Goodman, Grant K. 1995. "Philippine Bushido." In Nitobe Inazō: Japan's Bridge Across the Pacific, edited by John F. Howes, 119-32. Boulder, CO: Westview Press.

Hall, John Whitney. 1983. "Terms and Concepts in Japanese Medieval History: An Inquiry into the Problems of Translation.” Jounal of Japanese Studies 9: 1-32.

Hashimoto, Yorimitsu 橋本順光. 2011. "Soft Power of the Soft Art: Jiu-jitsu in the British Empire of the Early 20th Century." In Toyō bigaku to tōyōteki shiyui o tou: shokuminchi teikokuka no kattō suru Ajia-zō 東洋美学と東洋的思惟を 問う：植民地帝国下の葛藤するアジア像, edited by Inaga Shigemi 稲賀 繁美, 69-80. Kyoto: Kokusai Nihon Bunka Kenkyū Sentaa.

Hearn, Lafcadio. 1895. "Jiujutsu." In Out of the East: Reveries and Studies in New Japan, 183-242. Boston: Houghton.

Hobsbawm, Eric J. 1983a. "Introduction: Inventing Traditions." In The Invention of Tradition, edited by Eric J. Hobsbawm and Terence Ranger, 1-14. Cambridge: Cambridge University Press.

—.1983b. "Mass-Producing Traditions: Europe 1870-1914." In The Invention of Tradition, edited by Eric J. Hobsbawm and Terence Ranger, 263-307. Cambridge: Cambridge University Press.

Holmes, Colin, and A. H. Ion. 1980. "Bushidō and the Samurai: Images in British Public Opinion, 1894-1914.” Modern Asian Studies 14: 309-29.

Howes, John F., ed. 1995. Nitobe Inazō: Japan's Bridge Across the Pacific. Boulder: Westview Press.

Hurst, G. Cameron, III. 1990. "Death, Honor, and Loyality: The Bushido Ideal.” Philosophy East and West 40: 511-27.

Inoue, Shun 井上俊. 1998. "The Invention of the Martial Arts: Kanō Jigorō and Kōdōkan Judo." In Mirror of Modernity: Invented Traditions of Modern Japan, edited by Stephen Vlastos, 163-73. Berekely: University of California Press.

—. 2004. Budō no tanjō 武道の誕生 (The Birth of Budō). Tokyo: Yoshikawa Kōbunkan. Jensen, R. Geoffrey. 1992. "Jose Millan-Astray and the Nationalist 'Crusade' in Spain.” Journal of Contemporary History 27: 425-47.

Joris, Pierre. 1998. "Toward a Nomadic Concept of Translation." Translation Review 54: 10-14.

—. 1999. "Nomad Century Ahead." Boundary 2 (26): 152-5.

Josephson, Jason Ānanda. 2012. The Invention of Religion in Japan. Chicago: University of Chicago Press.

Karp, Ivan. 1997. "Does Theory Travel? Area Studies and Cultural Studies." Africa Today 44: 281-95. 
Kiku, Kōichi 㐘幸一. 2007. "Bushidō and the Modernization of Japanese Sports." In This Sporting Life: Sports and Body Culture in Modern Japan, edited by William W. Kelly, 39-53. New Haven: Yale University Council on East Asian Studies. Liang, Qichao 梁啟超. 1904. Zhongguo zhi wushidao 中國之武士道 (Bushido in China). Shanghai: Guangzhi Shuju 廣智書局.

Lebra, Joyce C. 1975. "The Significance of the Japanese Military Model for Southeast Asia." Pacific Affairs 48: 215-29.

Lehmann, Jean-Pierre. 1984. "Old and New Japonisme: The Tokugawa Legacy and Modern European Images of Japan." Modern Asian Studies 18: 757-68.

Masuzawa, Tomoko. 2005. The Invention of World Religions, or, How European Universalism was Preserved in the Language of Pluralism. Chicago: University of Chicago Press.

McGuckin, Eric. 2005. "Travelling Paradigms: Marxism, Poststructuralism and the Uses of Theory." Anthropologica 47: 67-79.

Nishigori Hiroshi, Rebecca Harrison, Jamiu Busari, and Tim Dornan. 2014. "Bushido and Medical Professionalism in Japan." Academic Medicine 89: 560-63.

Nitobé, Inazō [Nitobe Inazō 新渡戸稻造 (1862-1933)]. 1900. Bushido: The Soul of Japan - An Exposition of Japanese Thought. Philadelphia: The Leeds \& Biddle Co. Available on-line: https://archive.org/details/bushidosouljapa00nitogoog; https://catalog.hathitrust.org/Record/100334461.

—. 1905 (1900). Bushido: The Soul of Japan - An Exposition of Japanese Thought. Tenth revised and enlarged edition. With an introduction by William Elliot Griffis. And a new preface to the tenth edition. New York, G. P. Putnam's Sons. Available on-line: https://catalog.hathitrust.org/Record/001597613. 1909. Thirteenth Edition. Available on-line: <https:/www.gutenberg.org/ebooks/12096.

—. 1969 (1905; 1900). Bushido: The Soul of Japan - An Exposition of Japanese Thought. Reprinted. Rutland, VT: Charles E. Tuttle Co.

Owen, Michael. 1967. Beasts of Bushido. London: Scripts.

Pernikoff, O. A. (Ossip Alexandre; 1894-1952). 1943. "Bushido": The Anatomy of Terror. New York: Council on Books in Wartime.

Powles, Cyril H. 1995. "Bushido: Its Admirers and Critics." In Nitobe Inazō: Japan's Bridge Across the Pacific, edited by John F. Howes, 107-18.

Reynolds, E. Bruce. 2004. "Phibun Songkhram and Thai Nationalism in the Fascist Era." European Journal of East Asian Studies 3: 99-134.

Rodríguez-Navarro, María Teresa. 2011. "The reception of Ethical and Aesthetical values of Japanese Culture in the West: The translations of Nitobe's Bushido and Okakura's Book of Tea into Spanish.” In Cultural Translations: Proceedings of the Workshop/Symposium in Varberg and Kyoto, edited by Noriko Thunman, 41-60. Göteborg: University of Gothenburg. Available on-line: https://www.gu.se/english/research/publication?publicationId=149668. 
Russell of Liverpool (Edward Frederick Langley Russell, 1895-1981). 1958 (2002). The Knights of Bushido: A Short History of Japanese War Crimes. Rpt. Mechanicsburg, PA: Stackpole Books, 2002.

Said, Edward W. 1982. “Travelling Theory." Raritan 1: 41-67. Reprinted as chapter 10 in The World, the Text, and the Critic, 226-47. Cambridge, Mass.: Harvard University Press, 1983.

—. 1994. "Traveling Theory Reconsidered." In Critical Reconstructions: The Relationship of Fiction and Life, edited by Robert M. Polhemus and Roger B. Henkle, 251-65. Stanford: Stanford University Press.

—. 2000. "Invention, Memory, and Place." Critical Inquiry 26: 175-92.

Shooklyn, Samuel. 2009. "Moral Instruction in Budō: A Study of Chiba Chōsaku with a Translation of his Major Work." Ph.D. Dissertation. Quebec: McGill University.

Smith, Jonathan Z. 1998. "Religion, Religions, Religious." In Critical Terms for Religious Studies, edited by Mark C. Taylor, 269-84. Chicago: University of Chicago Press.

Stengers, Isabelle, ed. 1987. D'une science à l'autre: Les concepts nomades. Paris: Éditions du Seuil.

Sugarman, Martin. 2014. Under the Heel of Bushido: Last Voices of Jewish POWs of the Japanese in the Second World War. London: Vallentine Mitchell.

Sumika, Masayoshi. 2013. "Social Darwinism and Religion: The Cross-Cultural Experiences of Liang Qichao and Nitobe Inazō." Comparative Studies on Regional Powers 13: 185-95.

Thamsook, Numnonda. 1978. "Pibulsongkram's Thai Nation-Building Programme during the Japanese Military Presence, 1941-1945." Journal of Southeast Asian Studies 9: 234-47.

Tsai, Chen-Feng 蔡振豐 [Cai Zhenfeng]. 2010. “Zhongguo jindai wushidao linian de jiantao” 中國近代武士道理念的檢討 (Discussion of the Idea of the Warrior Way in Modern China). Taiwan dongya wenming yanjiu xueka 臺灣 東亞文明研究學刊 7:189-218.

Vlastos, Stephen, ed. 1998. Mirror of Modernity: Invented Traditions of Modern Japan. Berkeley: University of California Press.

Yuasa, Akira 湯浅 晃. 2001. “Bujutsu no kindaiteki tenkai 武術の近代的展開 (Modern Development of Martial Arts).” In Budō densho o yomu 武道伝書を 読む, 304-30. Tokyo: Nihon Budōkan.

Yoshioka, Hiroshi 吉岡洋. 1995. "Samurai and Self-Colonization in Japan.” In The Decolonization of Imagination: Culture, Knowledge and Power, edited by Jan Nederveen Pieterse and Bhikhu Parekh, 99-112. London: Zed Books. Available on-line: http://www.iamas.ac.jp/ yoshioka/SiCS/writing/en_essay_1995_samurai.html. 